\title{
Research on the Governance Efficiency of the Full Life Cycle of Retail Enterprises
}

\author{
Lyu Jingye ${ }^{1, a}$, Gui Yang ${ }^{1, b}$ \\ ${ }^{1}$ College of Management, Xi'an University of Science and Technology, Xi'an Shaanxi, China \\ aLyujy@xust.edu.cn \\ b953490461@qq.com
}

\begin{abstract}
The improvement of corporate governance efficiency is an important way to achieve high-quality economic development. This article takes retail enterprises as the research object, combines the three economic development stages of enterprise life cycle and high-speed growth stage, medium-speed growth stage and the new normal of economic development. Starting from the static and dynamic dimensions, the DEA and Malmquist index method are used for retail enterprises. Analyze the evolution process of governance efficiency. The results show that retail enterprises generally have the problem of redundant governance investment, and the total factor productivity of retail enterprises in each life cycle is showing a downward trend. On this basis, combined with the characteristics of the life cycle of retail enterprises, it puts forward suggestions for improving governance, and explores effective ways to improve the efficiency of retail enterprise governance.
\end{abstract}

Keywords: Retail Enterprises, Full Life Cycle, Governance Efficiency, DEA, Malmquist Index

\section{INTRODUCTION}

As socialism with Chinese characteristics has entered a new era, China's economy must achieve quality change, efficiency change and dynamism change, among which efficiency change is the core goal of high-quality development[1]. Corporate governance plays an important role in the process of economic development, and corporate governance efficiency is one of the effective evaluation indexes for the realization of corporate governance goals[2], as the core force of China's circulation industry, retail enterprises have a positive influence on the growth of the national economy. Drived by the new round of scientific and technological revolution, the upgrading of consumption concept, the transformation of sales model and the increasingly fierce competition in the retail market, the retail industry is undergoing an unprecedented fundamental transformation[3]. Therefore, improving governance mechanism and improving governance efficiency are the necessary prerequisite and important guarantee for the high-quality development of retail enterprises, as well as the internal requirements for the realization of highquality economic development.
In recent years, academic circles have explored the influence of ownership structure, ownership concentration and ownership incentive mechanism on corporate governance efficiency from the perspective of the internal governance mechanism of enterprises. Ze-bin Wang took listed companies in Taiwan as samples, used DEA benchmark model to calculate their operating efficiency values, and studied the relationship between corporate governance and operating performance[4]. Yusheng Kong adopts mixed model and related random effects model to study how corporate control and ownership concentration affect the value of listed companies in China[5].

Scholars have also made in-depth studies on corporate governance from the perspective of life cycle. Shuling \&Picheng divided the life cycle of listed companies into three stages: growth stage, maturity stage and decline stage according to the difference in dividend payout ratio, sales growth rate, capital expenditure and firm age[6]. Forcadell, F.J. et al. used relaxation variables and combined with institutional theory to analyze the differences in corporate efficiency between institutional Settings under different economic cycles[7].

Through the literature review found that scholars started a lot of research on corporate governance 
efficiency, but combined with the perspective of life cycle, the retail business management efficiency of the literature is relatively small, and the existing literature mainly focused on qualitative analysis and single factor influence of corporate governance efficiency, mostly without considering the retail business management efficiency under different economic background difference.

Therefore, based on the retail industry as the research object, the different stages of life cycle, to manage the cost, equity balance degree, management shareholding, shareholding proportion of independent directors, supervisors and other indicators as input variables, the total asset turnover and enterprise value as the output variable, the DEA model was used to construct the governance efficiency function, the different economic period retail efficiency of corporate governance problems, combined with its own life cycle changes the background of different enterprises, the influence factors of changes in the governance efficiency of retail industry is analyzed, and improvement measures are put forward for the existing problems, It provides the basis for establishing the effective corporate governance mechanism and promoting the governance efficiency of retail enterprises.

\section{MODEL BUILDING}

\subsection{Theoretical analysis and mechanism of action}

Corporate governance efficiency mainly evaluates the maximized output capacity or minimized input capacity when the output is fixed after the enterprise governance behavior. Theoretically speaking, governance efficiency, as a special performance index, can make up for the shortcomings of single index measurement and more comprehensively evaluate the level of corporate governance.

The internal governance structure of an enterprise mainly influences the governance efficiency through ownership concentration, ownership balance and ownership structure, and the influence degree of these factors is also different for retail enterprises in different life cycles. In different stages of the life cycle, the mechanism of the influence of enterprise ownership structure on governance efficiency is shown in Figure 1.
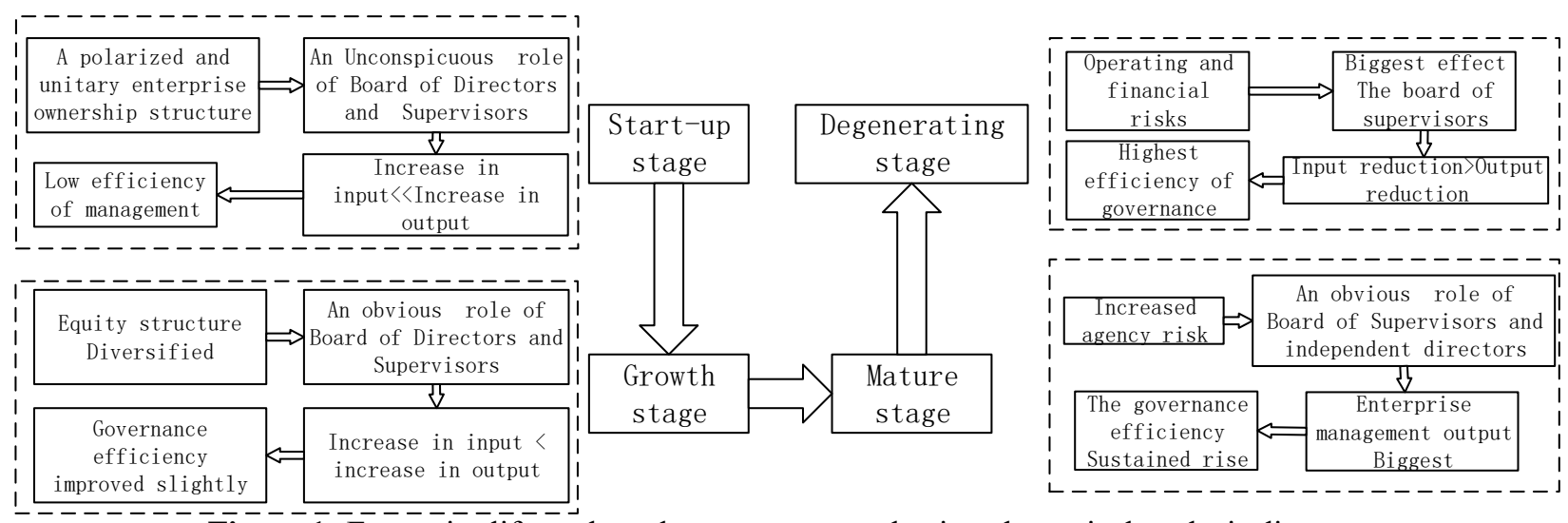

Figure 1 Enterprise life cycle and governance mechanism theoretical analysis diagram

\subsection{Research method}

\subsubsection{DEA method}

As one of the common methods of efficiency evaluation, DEA is a typical non-parametric method, which has a strong effect of management decision. This method has two basic models: BCC and CCR, which are suitable for the study of multi-input and multi-output problems. The advantage is that there is no need to predetermine the relationship between indicators before evaluating efficiency. There is no need to assign subjective weights, and the relative effectiveness of decision making units can be measured, and the reasons and degrees of ineffectiveness of decision making units can be pointed out.

If there are $\mathrm{N}$ decision units and assuming that returns to scale do not change, Equation (1) can represent Model
CCR. X and Y represent input and output respectively. In Equation (2), the symbol $\theta$ refers to the technical efficiency of the evaluated object. By introducing the remaining variables $\mathrm{S}^{-}$and the relaxation variable $\mathrm{S}^{+}$into Equation (2), the remaining variables can be transformed into equality constraints.

$$
(P)\left\{\begin{array}{l}
\max h_{j 0}=\mu^{T} y \\
\text { s.t. } \omega^{T} x_{j}-\mu^{T} y_{j} \geq 0, j=1,2, \ldots n \\
w^{T} x_{0}=1 \\
\omega \geq 0, \mu \geq 0
\end{array}\right.
$$




$$
\begin{gathered}
\left(D^{\prime}\right)\left\{\begin{array}{l}
\min \theta=1 \\
\text { s.t. } \sum_{j=1}^{n} \lambda_{j} x_{j} \leq \theta x_{0} \\
\sum_{j=1}^{n} \lambda_{j} y_{j} \geq y_{0} \\
\lambda j \geq 0, j=1,2, \ldots n \\
\theta i s \text { nconstrained }
\end{array}\right. \\
\text { (D) }\left\{\begin{array}{l}
\min \theta=1 \\
\text { s.t. } \sum_{j=1}^{n} \lambda_{j} x_{j}+s^{+} \leq \theta x_{0} \\
\sum_{j=1}^{n} \lambda_{j} y_{j}-s^{-} \geq y_{0} \\
\lambda j \geq 0, j=1,2, \ldots n \\
\theta i s u n c o n s t r a i n e d, s^{+} \geq 0, s^{-} \leq 0
\end{array}\right.
\end{gathered}
$$

There is no equality constraint for $\theta$ in the formula. When $\theta=1, \mathrm{~s}^{-}=0, \mathrm{~s}^{+}=0$, it indicates that the DEA model is valid. When $\theta=1, \mathrm{~S}^{-} \neq 0, \mathrm{~S}^{+} \neq 0$, the utility of this model is weak. When $\theta<1, \mathrm{~S}^{-} \neq 0, \mathrm{~S}^{+} \neq 0$, then the model has no utility.

CCR model calculates the value of general-efficiency. In order to decompose the value of general-efficiency into technical efficiency and scale efficiency, BCC model needs to be used to calculate the value of technical efficiency and finally calculate the scale efficiency. The BCC model is as follows:

$$
\left\{\begin{array}{l}
\min \theta=1 \\
\text { s.t. } \sum_{j=1}^{n} \lambda_{j} x_{j}+s^{+} \leq \theta x_{0} \\
\sum_{j=1}^{n} \lambda_{j} y_{j}-s^{-} \geq y_{0} \\
\sum_{j=1}^{n} \lambda_{j}=1 \\
\theta \text { is unconstrained, } s^{+} \geq 0, s^{-} \leq 0
\end{array}\right.
$$

In this thesis, the DEA-BCC model, which is most consistent with the connotation of enterprise governance, and the corresponding evaluation index of enterprise governance efficiency are adopted to conduct quantitative analysis on the governance efficiency of retail enterprises.

\subsubsection{Malmquist productivity index method}

Malmquist index is the product of the rate of change of technical efficiency and the rate of change of technological progress under the condition of constant returns to scale.

$$
T E P C H=E F F C H * T E C H C H
$$

Techch describes the proximity of each decision unit to the production front in the period $t$ to $t+1$, that is, the change degree of technical efficiency in the period $t$ to $\mathrm{t}+1$, which reflects the "level effect". In actual production and operation, Techch reflects the merits and demerits of enterprise management methods and the correctness of management decision layer.

Effch is the technology progress index, which measures the movement of the production front from $t$ to $\mathrm{t}+1$, reflecting the "growth effect". Horizontal effect means moving to the production possibility frontier and improving the technical efficiency. The growth effect means that the production possibility curve shifts, which promotes technological progress and thus leads to sustained economic growth.

The governance efficiency measured by DEA model is only for a specific period, and it analyzes the static comparison of the governance efficiency of retail enterprises. In order to explore the change of governance efficiency of different retail enterprises in different periods, the static comparison of governance efficiency in different years may lack accuracy due to the improvement of internal management technology or external market environment and other factors. Malmquist index can well reflect the dynamic change of the relative governance efficiency of retail enterprises.

\subsubsection{Index set}

\subsubsection{Enterprise life cycle demarcation metrics.}

In this thesis, Dickinson's net cash flow method is used for reference to divide the stages of enterprise life cycle, as shown in Table 1. After excluding the enterprises in the elimination stage, the life cycle is divided into the initial stage, the growth stage, the maturity stage and the decline stage combined with the data of the listed companies.

Table 1. The basis for classifying the life cycle of cash flow

\begin{tabular}{|ccccc|}
\hline Cash flow & $\begin{array}{c}\text { Initial } \\
\text { period }\end{array}$ & $\begin{array}{c}\text { growth } \\
\text { period }\end{array}$ & $\begin{array}{c}\text { maturity } \\
\text { period }\end{array}$ & $\begin{array}{c}\text { decline } \\
\text { period }\end{array}$ \\
$\begin{array}{c}\text { Operating } \\
\text { activities }\end{array}$ & - & + & + & - \\
\hline $\begin{array}{c}\text { Investment } \\
\text { activities }\end{array}$ & - & - & - & + \\
\hline $\begin{array}{c}\text { Financing } \\
\text { activities }\end{array}$ & + & + & - & $+/-$ \\
\hline
\end{tabular}




\subsubsection{Enterprise governance efficiency index}

Considering the feasibility of data collection, the representativeness of indicators and the availability of data, this paper combines domestic and foreign literatures and selects indicators mainly from the perspective of agency cost and enterprise governance mechanism. In the input index, the input variables representing the narrow sense agency cost are mainly selected: management expense, equity balance degree, management shareholding proportion, independent director proportion, and supervisor shareholding proportion. In the output index, the turnover of total assets reflects the utilization efficiency and management quality of enterprise assets.

In order to eliminate the influence of enterprise scale on input-output index, some adjustments have been made to the corresponding indexes. The specific indexes are selected and calculated as follows:

Table 2. Retail business management efficiency input output index calculation

\begin{tabular}{|c|c|c|c|}
\hline Type & $\begin{array}{l}\text { The } \\
\text { symbol }\end{array}$ & Index & Index explanation \\
\hline \multirow{7}{*}{$\begin{array}{c}\text { Input } \\
\text { indicators }\end{array}$} & $\mathrm{X}_{1}$ & Management fees & Overhead expenses/revenue \\
\hline & $\mathrm{X}_{2}$ & $\begin{array}{l}\text { Equity checks and } \\
\text { balances }\end{array}$ & $\begin{array}{l}\text { Number of shares held by the first shareholder /Total number } \\
\text { of shares held by the second to tenth shareholders }\end{array}$ \\
\hline & $X_{3}$ & $\begin{array}{l}\text { Management } \\
\text { shareholding ratio }\end{array}$ & Number of management shares/total number of shares \\
\hline & $\mathrm{X}_{4}$ & $\begin{array}{l}\text { Proportion of } \\
\text { Independent Directors }\end{array}$ & Number of independent directors/number of boards \\
\hline & $X_{5}$ & $\begin{array}{l}\text { Shareholding ratio of } \\
\text { directors }\end{array}$ & Number of shares held by directors/total number of shares \\
\hline & $X_{6}$ & $\begin{array}{l}\text { Scale of Board of } \\
\text { Supervisors }\end{array}$ & The number \\
\hline & $x_{7}$ & $\begin{array}{l}\text { Supervisor } \\
\text { shareholding ratio }\end{array}$ & Supervisor's number of shares/total number of shares \\
\hline \multirow{2}{*}{$\begin{array}{c}\text { Output } \\
\text { indicators }\end{array}$} & $Y_{1}$ & Total asset turnover & Operating revenue/total assets \\
\hline & $Y_{2}$ & The enterprise value & Tobin Q \\
\hline
\end{tabular}

\subsubsection{Sample selection and data sources}

Listed retail companies in 2010, 2014 and 2018 were selected as the research objects, and the research data came from CSMAR database. Most of the samples were traditional department stores, diversified supermarket chains and pharmaceutical retailers. When ST, ${ }^{*} \mathrm{ST}$ and sample companies with missing values were removed side by side, 178 sample companies were finally obtained, including 57 in 2010, 58 in 2014 and 63 in 2018.

\section{EMPIRICAL ANALYSIS}

\subsection{Description of the various life cycles of the enterprise}

Through the statistics of the number of retail enterprises in different life cycles, we can analyze the change of the number of enterprises in different economic growth stages and different life cycles.

As shown in Figure 2, on the whole, retail enterprises in the mature stage account for $45 \%$ of the total sample every year, and retail enterprises in the growing stage account for $30 \%$ of the total sample every year. Generally speaking, the vast majority of retail enterprises in China are in the growth and maturity stage, the proportion of retail enterprises in the initial stage is relatively small, and the number of retail enterprises in the recession stage is the least. This phenomenon is consistent with the change of our country economy background, in 2014 the Chinese economy bid farewell to around $10 \%$ of highspeed growth, to seek improvement in stability, quality, and the efficiency of the medium growth stage, the contribution of consumption to GDP growth of $51.2 \%$, become the main drive economic growth, which is closely related to its present situation of retail enterprises, in the growth and maturation of retail enterprises contributed most of retail industry as a whole.

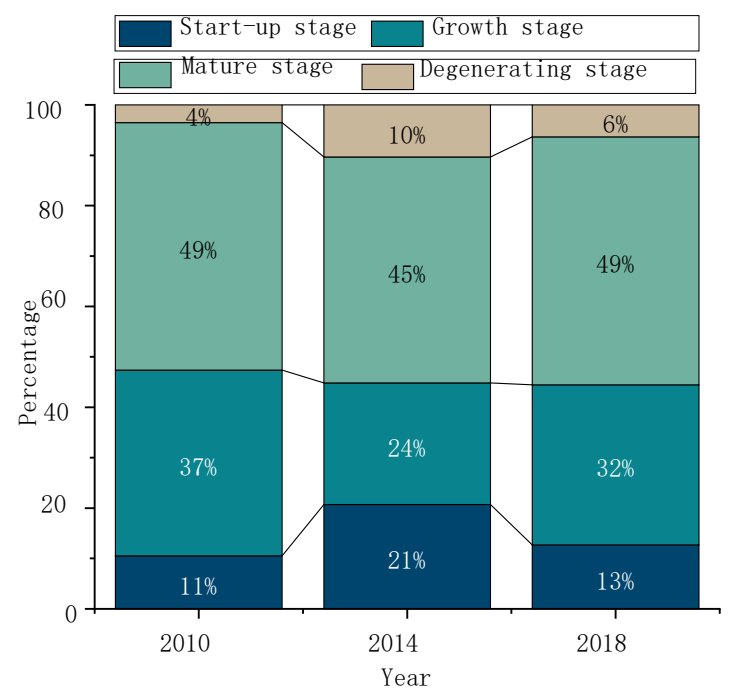

Figure 2 Changes in the proportion of enterprises in samples at different stages 
From the trend point of view, the proportion of retail enterprises in the initial period increases greatly in the stage of economic growth decline, and falls to a lower level in the stage of new normal economic development. On the contrary, the growth stage of retail enterprises, the market share reached $32 \%$ in 2018 ; In the mature period of the retail enterprise market accounted for $49 \%$ or so. It shows that with the improvement of economic quality, the retail enterprises in the initial period are rapidly transforming to the growth period. Combined with the market economy, the retail enterprises in the growth period optimize their own ownership structure, explore their core competitiveness, and develop effective strategic planning to further expand the market. Retail enterprises in the mature period can stabilize their market share by strengthening basic management and optimizing organizational structure.

\subsection{Efficiency analysis based on DEA}

\subsubsection{Overall evaluation of governance efficiency}

The higher the general-efficiency value is, the higher the governance efficiency is. Pure technical efficiency is a measure index of the internal governance environment, mechanism and enterprise management level of decision making unit. From the perspective of governance efficiency of China's retail enterprises, the generalefficiency and scale efficiency of governance of China's retail enterprises in 2010, 2014 and 2018 are not high, while the pure technical efficiency of governance is high. The details are shown in Table 3.

Table 3. Retail business overall management efficiency changes

\begin{tabular}{|ccccc|}
\hline Year & General-efficiency & Pure technical efficiency & scale efficiency & Effective ratio of treatment \\
$\mathbf{2 0 1 0}$ & 0.79 & 0.94 & 0.84 & 0.28 \\
\hline $\mathbf{2 0 1 4}$ & 0.81 & 0.98 & 0.82 & 0.39 \\
\hline $\mathbf{2 0 1 8}$ & 0.83 & 0.99 & 0.84 & 0.33 \\
\hline mean value & 0.81 & 0.97 & 0.83 & 0.33 \\
\hline
\end{tabular}

From Table 3, it can be seen that the mean of the general efficiency of China's retail enterprises' governance fluctuates around 0.81 , the mean of the pure technical efficiency is close to 1 every year, and the change trend of the mean of the scale efficiency and the mean of the general efficiency is consistent. However, the proportion of Chinese retail enterprises at the forefront of production fluctuates about $33 \%$. It shows that the improvement space of China's retail enterprise governance efficiency is slightly larger than that of ineffective enterprises. In China, the pure technical efficiency of retail enterprise governance is better, and the overall management level of retail enterprise is higher, while the scale efficiency of retail enterprise governance has the greatest influence on the general efficiency of governance. Therefore, the unscientific allocation of input resources is the main factor leading to the general efficiency of governance.

The following will use the projection analysis, in order to find out such as: Hefei Department Store, Zhangzhou Development, Gaohong shares, Nanjing Xinbai, Eurasia Group, friendly group, Shanghai nine hundred and Beijing urban and rural retail enterprises did not achieve the management efficiency and effectiveness of the reasons.

\subsubsection{Analysis of enterprise inefficiency management}

The slack variable results of input-output index in the model are statistically analyzed, and the differences in governance input index between inefficient and effective retail enterprises and those with excellent governance performance are specifically discussed, and the reasons for low governance efficiency of retail enterprises are summarized. Only in this way can the non-effective units of DEA be converted into effective units of DEA. In Figure 3, the $\mathrm{Y}$ axis represents the proportion of enterprises with redundancy in the total. The higher the proportion, the input redundancy of these decisionmaking units with relatively ineffective governance, thus affecting the efficiency of enterprise governance.

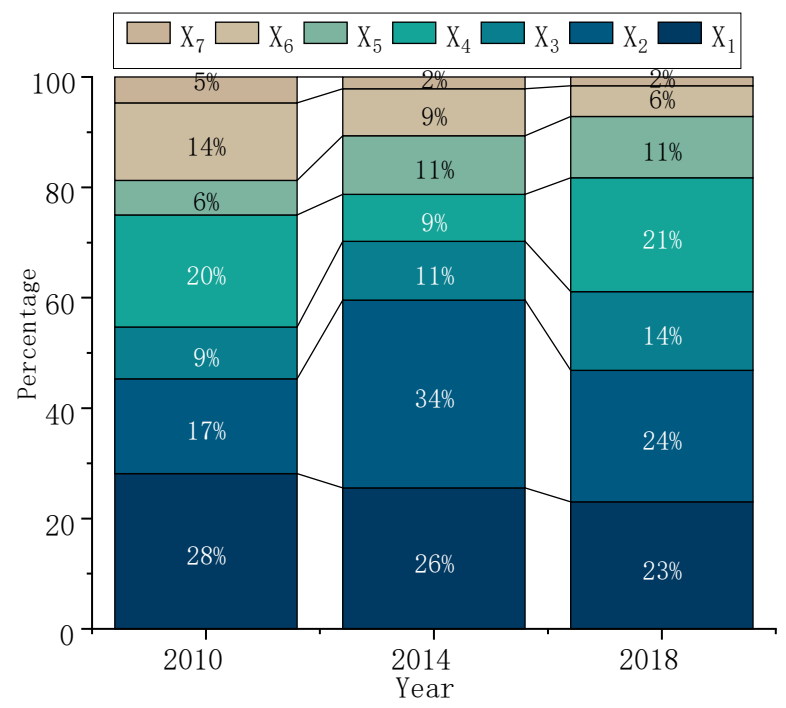

Figure 3 Change of input index redundancy ratio

Specifically, among the decision units with redundant inputs, the proportion of administrative cost redundancy is the largest, and it remains high in all stages of high- 
quality economic development, accounting for about $26 \%$ per year. Showed that the retail enterprise with the excellent enterprise compared to front, the technical efficiency value, there is still a large space, can take to improve the statistical system of enterprises, improve enterprise management level, applying scientific management methods, the cost management of fine control, reduce the degree of redundancy management cost, promote the long-term development of the enterprise. However, after the rapid economic development, the ratio of redundancy of equity balance increased significantly, reaching the highest of $34 \%$. Under the background of the separation of the two rights, the increase of agency cost promotes the effect of equity balance from the initial stage to the growth stage, but this positive effect is weakened due to the continuous improvement of corporate governance system. As incentive dimensions, the size of the board of supervisors and the shareholding ratio affect the efficiency of corporate governance. Compared with other input indicators, the proportion of enterprises with redundant investment every year is the least, less than $10 \%$. It shows that the influence degree on corporate governance efficiency is relatively small. In the meantime of high- quality economic development, China's legal system also tends to be improved correspondingly. The setting of the board of supervisors is more standardized, while the shareholding ratio of senior executives is more independent in the distribution right.

\subsubsection{Analysis of governance efficiency in different life cycle stages}

Enterprises in different life cycles have different governance efficiency due to different governance mechanisms. According to the efficiency analysis of enterprises with different life cycle types, it can be seen from Table 4 that the change trend of governance efficiency in each life cycle stage is consistent with the change trend of the proportion of enterprises in different life cycle stages mentioned above. In 2010, the retail enterprises in the mature stage had the best governance level, and the average governance efficiency reached 0.87 . In 2014, the average governance efficiency of mature retail enterprises was the highest, reaching 0.9. However, in 2018, the overall governance efficiency of retail enterprises in each life cycle performed well, all of which were above 0.83 .

Table 4. Comparison of efficiency and effectiveness of enterprises in different stages of life cycle

\begin{tabular}{|c|c|c|c|c|c|c|c|}
\hline \multirow{2}{*}{ Year } & \multirow{2}{*}{$\begin{array}{l}\text { Life cycle } \\
\text { Stage }\end{array}$} & \multicolumn{2}{|c|}{ General-efficiency } & \multicolumn{2}{|c|}{$\begin{array}{l}\text { Pure technical } \\
\text { inefficiency }\end{array}$} & \multicolumn{2}{|c|}{ scale efficiency } \\
\hline & & $\begin{array}{l}\text { mean } \\
\text { value }\end{array}$ & int cnt & mean value & int cnt & mean value & int cnt \\
\hline \multirow{4}{*}{2010} & initial period & 0.66 & 1 & 0.87 & 1 & 0.73 & 1 \\
\hline & $\begin{array}{l}\text { Growth } \\
\text { period }\end{array}$ & 0.77 & 4 & 0.92 & 11 & 0.84 & 4 \\
\hline & mature period & 0.87 & 13 & 0.98 & 18 & 0.89 & 13 \\
\hline & decline period & 0.56 & 0 & 0.89 & 0 & 0.61 & 0 \\
\hline \multirow{4}{*}{2014} & initial period & 0.75 & 4 & 0.98 & 10 & 0.75 & 4 \\
\hline & $\begin{array}{l}\text { Growth } \\
\text { period }\end{array}$ & 0.8 & 6 & 0.98 & 12 & 0.81 & 6 \\
\hline & mature period & 0.9 & 15 & 0.99 & 22 & 0.9 & 15 \\
\hline & decline period & 0.6 & 1 & 0.96 & 4 & 0.63 & 1 \\
\hline \multirow{4}{*}{2018} & initial period & 0.83 & 3 & 0.99 & 7 & 0.84 & 3 \\
\hline & $\begin{array}{l}\text { Growth } \\
\text { period }\end{array}$ & 0.85 & 6 & 1 & 19 & 0.85 & 6 \\
\hline & mature period & 0.83 & 13 & 0.98 & 28 & 0.84 & 13 \\
\hline & decline period & 0.9 & 2 & 1 & 4 & 0.9 & 2 \\
\hline
\end{tabular}

As can be seen from Table 4, in each stage of economic growth, the average general efficiency of enterprises in the mature stage is basically higher than that of enterprises in other life cycles. Only in the new normal stage of economic development, the average general efficiency of enterprises in the mature stage is slightly lower than that of enterprises in the growth stage. The average general efficiency of enterprises in the initial period, growth period and decline period increases year after year. Is shown in figure 1 the reason: in combination with enterprise life cycle and governance mechanism of the theory analysis and cycle of retail enterprise statistic result shows that most of the retail enterprises in growth period and mature period, in the growth of enterprises, the scale expands rapidly, with more investment and growth opportunities, the improvement of ownership concentration will help decrease the cost of management and supervision, improve the governance efficiency. In the mature period of the enterprise, enterprise status, market share is relatively stable, its governance efficiency is also improved accordingly.

The general efficiency, pure technical efficiency and scale efficiency value are 1 in three years. The enterprises that have achieved the effective governance efficiency successively include four retail enterprises, such as 
Belian Co., Ltd., Neiwang Bio, Yimin Group, and Xinhuadu. In terms of equity checks and balances, the proportion of independent directors and other aspects are adjusted with the change of economic growth. Of bailian shares as domestic first-class large-scale comprehensive business enterprise, its business covers all kinds of retailing formats, is given priority to with department store, supermarket chains to diversified management and shopping center, along with the economy situation change its internal structure adjustment, the largest equity balance degree reduced from 1.828 in 2010 to 2014 to 0.214 , the independent directors proportion changed from $4.5 \%$ in 2010 to $0.273 \%$ in 2018 , went through its life cycle by the transition of the maturity to recession and growth.

\subsection{Dynamic efficiency analysis based on Malmquist exponential method}

The previous paper only analyzes the static governance efficiency of retail enterprises in each year.
In order to further study the change of governance efficiency of retail enterprises under different economic conditions, this paper applies Malmquist DEA index method to analyze 33 enterprises in continuous operation from 2010 to 2018, and carries out longitudinal comparative analysis on the change of total factor productivity growth of enterprises in different life cycle stages.

According to Table 5 below, the TFP index of 33 selected retail enterprises from 2010 to 2018 was 1.27 . Therefore, on the whole, the governance efficiency of the sample enterprises increased by $27 \%$ on average, indicating that the overall governance efficiency is rising rapidly. However, from the perspective of influencing factors, the change index of technical efficiency remained at about 1 during the two periods, while the TFP index decreased from 2.424 to 0.666 . Therefore, the improvement of governance efficiency mainly comes from technological progress.

Table 5. Overall Malmquist mean value and decomposition of retail enterprises

\begin{tabular}{|c|c|cccc}
\hline Year & $\begin{array}{c}\text { Change in } \\
\text { technical } \\
\text { efficiency }\end{array}$ & EFFCH & $\begin{array}{c}\text { pure technical } \\
\text { inefficiency }\end{array}$ & scale efficiency & TFP index \\
\hline $\mathbf{2 0 1 0 - 2 0 1 4}$ & 1.014 & 2.389 & 1.01 & 1.004 & 2.424 \\
\hline $\mathbf{2 0 1 4 - 2 0 1 8}$ & 1.052 & 0.633 & 1 & 1.052 & 0.666 \\
\hline Mean value & 1.033 & 1.23 & 1.005 & 1.028 & 1.27 \\
\hline
\end{tabular}

According to the above DEA calculation results, the contribution of scale efficiency to general efficiency is greater than that of pure technical efficiency. Therefore, the growth rate of the technology progress index does not match the actual development of technology.

Under the impact of online shopping, traditional retail enterprises have tried to innovate their business forms and realize self-improvement of technical efficiency. Some retail enterprises swing between traditional retail and new retail, which generally reduces the level of technological progress and leads to a low growth rate of governance efficiency.

The life cycle changes of these 33 enterprises are classified in the following, and the selected three years are divided into two change periods by Malmquist index method.

The enterprises that develop from the initial period to the growth or maturity period are classified as progressive enterprises; The enterprises with no life cycle phase changes during the period are classified as sustainable development enterprises; At the same time, the enterprise that enters the decline period and develops from the mature period or the growth period to the initial period is classified as the regressive enterprise. At the same time of making statistics on sample enterprises, combined with the change of total factor productivity, the changes of technical efficiency and technical changes of enterprises with different evolution types are analyzed respectively, as shown in Table 6 .

Table 6. Analysis on the change of total factor productivity in different life cycle evolution types of retail enterprises

\begin{tabular}{|c|c|c|c|c|}
\hline $\begin{array}{l}\text { The life cycle } \\
\text { evolves the } \\
\text { enterprise type }\end{array}$ & Sample period & $\begin{array}{c}\text { Technical Efficiency } \\
\text { Change }\end{array}$ & $\begin{array}{l}\text { Technical } \\
\text { change }\end{array}$ & TFP change \\
\hline \multirow{2}{*}{$\begin{array}{c}\text { Progressive } \\
\text { enterprise }\end{array}$} & 2010-2014（6） & 1.145 & 3.157 & 3.691 \\
\hline & $2014-2018(11)$ & 1.189 & 0.595 & 0.724 \\
\hline \multirow{2}{*}{$\begin{array}{l}\text { Maintenance } \\
\text { enterprise }\end{array}$} & $2010-2014(13)$ & 1.067 & 2.604 & 2.769 \\
\hline & $2014-2018(18)$ & 1.028 & 0.661 & 0.686 \\
\hline \multirow{2}{*}{$\begin{array}{l}\text { Regressive } \\
\text { enterprise }\end{array}$} & 2010-2014（14） & 0.963 & 2.169 & 2.031 \\
\hline & 2014-2018 (3) & 1 & 0.902 & 0.902 \\
\hline
\end{tabular}


Table 6 is the mean summary of TFP index, technological change and pure technological change efficiency of all kinds of retail enterprises during the sample period. Between 2010 and 2014 various types of retail enterprises have progress, and progress of retail enterprises average TFP index is 3.691 , may be due to the 2010-2014, entity retail electricity shock, plus a its augean stables, companies adjust innovation, invest a lot of capital to promote online fusion, so the enterprise's total factor productivity at an annual rate of three times during the study period.

From 2014 to 2018, all types of retail enterprises showed a regression, with the average TFP index less than 1. During this period, digitization has become the infrastructure, the integration of information and technology has been improved, online retail after years of development, the penetration rate of e-commerce is extremely high, and the dividend of online traffic has bottomed out. Some retail and pure e-commerce enterprises will gradually shift the focus of development to offline; The development of retail relies on the progress of basic technology. With the technological innovation in other fields, the application in the retail link still needs to explore the practical effect gradually. However, the number of progressive enterprises and maintaining enterprises increased year by year, and the number of regressive enterprises decreased from 14 to 3 , indicating that technology investment can help retail enterprises to achieve sound development to a certain extent.

The vertical change trend of TFP growth rate of all kinds of retail enterprises showed a downward trend, which was consistent with the overall enterprise background. Thus it can be seen that the future model exploration and landing of retail enterprises need a lot of governance investment and strong capital support.

\section{CONCLUSION}

In this paper, the DEA-Malmquist model is used to measure the governance efficiency of retail enterprises from the dynamic and static perspectives, and analyze it from the perspective of enterprise life cycle. The results show that :(1) From 2010 to 2018, the comprehensive governance efficiency of retail enterprises has been increasing year by year. About $42 \%$ of enterprises have input redundancy in the aspects of management costs, equity balance and proportion of independent directors, and about $38 \%$ of enterprises have reached the effective level of governance efficiency. (2) From the static perspective, pure technical efficiency plays a more significant role than scale efficiency in improving the governance efficiency of retail enterprises; (3) From the dynamic perspective, in the process of enterprise development, both pure technical efficiency and scale efficiency are improved, but the efficiency of technological progress decreases, that is, the degeneration of technological level leads to the decline of enterprise governance level; (4) Among the sample enterprises, Neyang Bio, Xinhuadu and Belian share have the best performance in governance efficiency. Technological progress and improvement of operation and management level are the important reasons for the improvement of governance efficiency.

In order to effectively improve the governance efficiency of retail enterprises, the following suggestions are proposed based on the empirical results :(1) Enterprises should combine the characteristics of their own development stages to avoid investment redundancy in the initial stage; (2) In the growth and maturity stages, while expanding the operation scale, we should emphasize the scale of supervision institutions and give play to the role of equity incentive to prevent the abuse of power; (3) in the recession stage, while streamlining the structure, scientific and reasonable investment, strengthen the internal governance of the enterprise, reduce the agency cost of the enterprise, extend the life cycle of the enterprise as far as possible; (4) Retail enterprises should keep up with the pace of technological upgrading, pay attention to their own evolution and upgrading, make the business connotation and means more close to the mainstream of consumption of The Times, and then promote the positive change of enterprises, improve the governance efficiency of retail enterprises, and promote the high-quality development of retail enterprises.

\section{ACKNOWLEDGMENTS}

This work was supported by Postdoctoral Foundation of $\mathrm{Xi}$ 'an University of Science and Technology (8250119003) and Prosperity Philosophy and Social Science Project of $\mathrm{Xi}$ 'an University of Science and Technology.

\section{REFERENCES}

[1] Dhar, B. K., \& Mutalib, M. (2020) Leadership of Xi Jinping behind Unstoppable Sustainable Economic Growth of China. International Journal of Organizational Leadership, 9, 39-47.

[2] Khan, A., Muttakin, M. B., \& Siddiqui, J. (2013) Corporate governance and corporate social responsibility disclosures: Evidence from an emerging economy. Journal of business ethics, 114(2), 207-223.

[3] Xu, X., Bu, Z., \& Fan, Z. (2020) Research on Marketing Strategy of B2C E-Commerce Platform Based On Marketing Strategy Triangle Model. In 5th International Conference on Financial Innovation and Economic Development (ICFIED 2020) (pp. 314-319). 
[4] Wang, Z. B., Chiu, Y. H., Hsieh, J. C., Li, Y., \& Hsiao, L. H.. (2018) Performance appraisal for the operation and management of listed and otc taiwanese companies with dea benchmarking models. Journal of the Asia Pacific Economy, 1-18.

[5] Kong, Y., Famba, T., Chituku-Dzimiro, G., Sun, H., \& Kurauone, O. (2020) Corporate governance mechanisms, ownership and firm value: evidence from listed Chinese firms. International Journal of Financial Studies, 8(2), 20.

[6] Chiang, S., Lee, P., \& Anandarajan, A. (2013) Corporate governance and innovative success: An examination of the moderating influence of a firm's life cycle stage. Innovation, 15(4), 500-514.

[7] Forcadell, F. J., Sanchez-Riofrio, A., GuerrasMartín, L. Á., \& Romero-Jordán, D. (2020) Is the restructuring-performance relationship moderated by the economic cycle and the institutional environment for corporate governance? Journal of Business Research, 110, 397-407.

[8] Dickinson, V. (2011) Cash flow patterns as a proxy for firm life cycle. The Accounting Review, 86(6), 1969-1994. 